\title{
A ANTROPOLOGIA FILOSÓFICA DE IMMANUEL KANT: MORALIDADE, AFETOS E PAIXÕES
}

\author{
IMMANUEL KANT'S PHILOSOPHICAL ANTHROPOLOGY: MORALITY, AFFECTIONS AND \\ PASSIONS
}

Renata Cristina Lopes Andrade

Universidade Federal do Rio Grande, Rio Grande, RS, Brasil E-mail: renatacrlopes@yahoo.com.br

DOI: https://doi.org/10.46550/amormundi.v1i2.23

Recebido em: 11.09.2020

Aceito em: 02.11.2020

Resumo: $O$ presente artigo explora o pensamento de Immanuel Kant, particularmente, na obra Antropologia de um ponto de vista pragmático. Oferecemos a compreensão da Antropologia estabelecendo as relaçóes e as conexóes entre: afeto, paixão, moralidade e ética. Enxergamos na obra Antropologia de um posto de vista pragmático o momento em que Kant realiza, com maior precisão, suas consideraçóes acerca dos afetos, das paixóes -os dois estados da alma pertencentes à faculdade de desejar - e do lugar da sensibilidade junto da moralidade e da ética.

Palavra-chave: Afecção, Paixão, Moralidade, Kant.

Abstract: This article explores the thought of Immanuel Kant, particularly in the work Anthropology from a pragmatic point of view. We offer an understanding of Anthropology by establishing the relationships and connections between: affection, passion, morality and ethics. We see in the work Anthropology from a pragmatic point of view the moment when Kant realizes, with greater precision, his considerations about the affections, the passions - the two states of the soul belonging to the faculty of desire - and the place of sensitivity next to morality and of ethics.

Keyword: Affection, Passion, Morality, Kant.

\section{Introduçáo}

$\mathrm{N}$

a obra Antropologia de um ponto de vista pragmático (1798), Kant nos fala sobre dois estados da alma pertencentes à faculdade de desejar, a saber: as afecçôes e as paixóes.

Considerando o ser humano, as suas ações, a sua conduta, o seu comportamento, bem como o valor que a sua ação pode apresentar, pensamos ser importante a compreensão de tais estados da alma, afinal, como alerta o filósofo, o ser humano não é um ser apenas dotado de razão, encontra-se, também, sujeito à sensibilidade, que pode ser o motivo ou determinante da sua vontade em suas realizaçôes, além da sua razão. Isso significa que a razão não é, para o ser humano, inteiramente senhora da sua faculdade de desejar/faculdade de querer.

Assim, importa compreender o que são as afecçôes e as paixões na concepção do filósofo, 
se as afecções ou as paixôes são benéficas ou não ao valor (moral) da ação, se auxiliam ou atrapalham a vida moral, em resumo, qual o lugar da constituição sensível do ser humano, qual o lugar das afecçóes, das paixóes tendo em vista a vida moral do ser humano.

Cabem, inicialmente, antes de nos determos na constituição sensível da natureza humana, algumas consideraçóes sobre a Vontade apresentada por Kant enquanto uma faculdade de desejar, de apetição ou volição. De acordo com Kant, a vontade é uma faculdade capaz de determinar-se a si própria a agir em conformidade com a representação de certas leis:

Tudo na natureza age segundo leis. Só um ser racional tem a capacidade de agir segundo a representação das leis, isto é, segundo princípios, ou: só ele tem uma vontade. (KANT, 1980, p. 123).

Isto significa que somente o ser racional apresenta uma vontade que pode ser evidenciada pela capacidade humana de agir segundo a representaçáo de leis, isto é, segundo princípios, leis representadas por si mesmo, diferentemente, por exemplo, de leis naturais. Noutras palavras, a capacidade de agir a partir da representação de leis chama-se, segundo Kant, vontade.

Vemos que a vontade, segundo a perspectiva kantiana, é uma faculdade própria do ser racional de agir mediante a representação de certa normatividade. No entanto, para o caso do ser humano, por sua constituição dual, por não ser meramente um ser racional, mas, também, sensível, essa norma pode estar diretamente ligada ou i) à sua constituição sensível - afetos, paixóes, impulsos, inclinaçóes - eis uma vontade (Willkür) sensivelmente afetada e a escolha e decisóes ocorrem (é causada) pela sensibilidade ou ii) à princípios (leis) práticos oriundos de uma razão prática que se apresenta enquanto legisladora e se identifica com a vontade do ser humano - eis uma vontade (Wille) não afetada, enquanto razão de determinaçáo, por qualquer sensibilidade e a escolha, decisão ou o motivo de uma ação será o respeito, reconhecimento e adoção da lei prática.

O que queremos evidenciar é que em Kant a vontade humana é inerente a uma faculdade/ capacidade de oferecer-se leis, de agir segundo a representação de regras ou leis, por (Willkür) ou independentemente (Wille) da coerção da sensibilidade ${ }^{1}$.

Se há essa dupla possibilidade, se a vontade pode ser coagida pelas inclinaçóes sensíveis, as representaçôes mediante as sensaçóes, tal como do sentimento de agradável ou desagradável, e pela racionalidade prática, as representaçôes mediante princípios morais, se a vontade pode seguir as prescriçôes da lei prática e agir segundo máximas morais ou se render aos impulsos sensíveis e agir segundo máximas gerais, onde é então, tendo em mente o valor moral da ação humana, o lugar da sensibilidade, o lugar da constituição sensível da natureza humana?

Se, de acordo com Kant, somente na açáo precisamente por dever (moral ou de virtude) é que compreendemos o sentido de agir segundo razóes morais, bem como a possibilidade de uma ação virtuosa ${ }^{2}$, se somente mediante a ação por dever (a vontade em si mesma) é que o ser humano sabe e segue (faz/realiza) exatamente o que deve ser feito do ponto de vista da moralidade, o que vamos abranger buscar expor, neste momento, é justamente a constituição sensível do ser humano, para compreendermos: o seu lugar, se auxilia ou prejudica no movimento do ser racional humano em sentido de sua moralidade, ou seja, se auxilia ou não a possibilidade

1 Para a distinção entre Willkür e Wille seguimos a interpretação sugerida por Henry E. Allison em Kant's theory of freedom. Cambridge University Press, NewYork, 1990, pp. 129-131.

2 "Virtude é a força da máxima do homem em sua obediência ao seu dever". Cf. Immanuel Kant. The Metaphysical elements of ethics. Forgotten Books, Hong Kong, 2008, p. 13. 
do pleno desenvolvimento moral da natureza humana, a vida do ser humano enquanto agente moral e livre ${ }^{3}$. Em suma: qual o lugar da sensibilidade no desenvolvimento e efetivaçáo da capacidade da razão prática? qual lugar da constituição sensível do ser humano tendo em mente a sua vida moral comum, a sua ação em geral com valor moral? o que são (definição, descrição, característica) e qual o lugar dos estados sensíveis pertencentes à faculdade de desejar?

$\mathrm{Na}$ Crítica da razão prática Kant realiza a distinção entre a faculdade de desejar superior e a faculdade de desejar inferior, diz ele:

Todas as regras práticas materiais póem o fundamento determinante da vontade na faculdade de apetiçáo inferior e, se não houvesses nenhuma lei meramente formal da vontade, que a determinasse suficientemente, não poderia tampouco ser admitida uma faculdade de apetição superior. (KANT, 2003 p. 77).

Nos deteremos aqui na faculdade de desejar (apetição) inferior, ou seja, na determinação sensível (material) da vontade.

\section{Moralidade, afetos e paixóes}

Nos parágrafos iniciais do livro terceiro da Antropologia, Kant apresenta uma série de definiçôes gerais acerca de alguns elementos humanos sensíveis: apetite, apetite sensível, inclinação, desejo, desejo vazio, ânsia, desejo humoroso, paixão, afecção. Vamos analisar, em particular, os seguintes elementos: inclinação, afecção e paixão. Vejamos.

Segundo Kant, o apetite sensível habitual, o desejo sensível que serve de regra ou hábito ao sujeito, chama-se inclinação. Por apetite entende-se a autodeterminação de um sujeito mediante a representação de algo futuro enquanto um efeito seu, tendo em vista que diz respeito a uma determinaçãoo segundo representação, trata-se de a uma ação futura que se espera algo enquanto efeito por vontade - voluntária.

$\mathrm{Na}$ Fundamentação da metafísica dos costumes (1785), Kant já oferece uma definição de inclinação a qual vemos completada, posteriormente, pela Antropologia (1798). Na Fundamentação: "Chama-se inclinação a dependência em que a faculdade de desejar está em face das sensaçôes” (KANT, 1980, p. 124). Podemos compreender que o apetite sensível habitual ou a faculdade de desejar face às sensações, mediante a representação de algo futuro enquanto efeito de uma ação segundo ou por vontade, é uma inclinação. O que queremos precisamente ressaltar é a faculdade de desejar que, quando dependente de alguma ou qualquer sensação ${ }^{4}$, temos o que podemos chamar de inclinação.

$\mathrm{Na}$ Antropologia Kant diz que uma determinada inclinação, apetite sensível ou a faculdade de desejar diretamente ligada às sensaçôes, que a razão do indivíduo dificilmente pode dominar, ou não pode dominar de modo algum, é uma paixão. Em contrapartida, a inclinação, apetite sensível ou a faculdade de desejar diretamente ligada às sensaçôes, sustentada por algum sentimento 5 , por exemplo, de prazer ou desprazer, satisfação ou dor, agradável ou desagradável,

3 Vale lembrar que na Antropologia a investigação acerca do ser humano enquanto um agente (atuante) moral e livre forma, ademais, o que Kant chamou de conhecimento do mundo sob a perspectivas pragmática, o conhecimento pragmático do ser humano, que está ligado à investigaçáo acerca do que o ser humano faz de si mesmo ou pode e deve fazer como um ser que age livremente.

4 A capacidade de experimentar o sentimento, por exemplo, de prazer ou de dor é sensação. Cf. Lewis White Beck. $A$ commentary on Kant's Critique of Practical Reason. University of Chicago Press, Chicago, 1984, p. 93.

5 Segundo Beck, o sentimento é uma espécie de afecção da sensibilidade em geral. (BECK, 1984, p. 93). 
alegria ou tristeza, amor, ira, no estado presente (o agora) que não permite a reflexão racional aflorar no indivíduo, por exemplo, se se deve entregar ou resistir ao sentimento, é afecção.

Justamente pela ausência da reflexão, a afecção (estar afetado ou afeto), de acordo com Kant, é apressada, representa uma comoção passageira, um apetite sensível, o que se quer ou pode querer face às sensaçóes, sustentada ou guiada por um sentimento presente/atual, o qual pode passar rapidamente de um grau para outro, o que torna a ponderaçáo e reflexão cada vez mais impossível, improvável, inconsiderada, o que pode fazer com que o ser humano perca facilmente a sua tranquilidade e a avaliação em suas açóes. Por outro lado, a paixão (a inclinação denominada paixáo), um apetite sensível, o que se quer ou pode querer face às sensaçóes, por não haver a presença do sentimento ou não ser sustentada por um sentimento apenas presente e atual, não tem pressa, é possível nesse caso a reflexão, o indivíduo é capaz de refletir, por exemplo, para alcançar o seu fim ambicionado. O que sustenta a paixão é o próprio objeto ou fim que se quer e, por mais violenta que possa ser a paixão, ainda assim há o espaço para a reflexão e ajuizamento. Exemplificando:

O que a afecção da ira não faz a toda velocidade, ela não faz de modo algum, e facilmente esquece. A paixão do ódio, porém, não te pressa em se enraizar profundamente para pensar em seu inimigo. (KANT, 2009, p. 150).

Vale observar que a paixão bem como a afecção são estados da alma, a primeira, um estado menos apressado, a segunda, um estado mais breve, o estado presente/agora, são pertencentes à faculdade de desejar, como a faculdade de desejar, nesses casos, apresenta-se diretamente ligada, dependente das (ou de alguma) sensaçóes, as paixôes, tanto quanto as afecção, são caracterizadas enquanto uma inclinação.

No que diz respeito às afecçóes humanas, Kant aponta que, de modo geral, o que constitui o estado de afecção não é precisamente a intensidade ou força de um determinado sentimento, mas, muito antes, a ausência ou a impossibilidade da reflexão, ao ponto de não poder comparar o sentimento presente com a soma de todos os sentimentos, resumindo-se sempre a um caso em particular. Mediante dois exemplos oferecidos por Kant na Antropologia podemos compreender com mais precisão o que constitui um estado de afecção, bem como a sua grande falta, isto é, a ausência ou impossibilidade de reflexão.

Muitos desejam até mesmo poder se zangar, e Sócrates tinha dúvida se não seria bom se zangar às vezes; mas ter a afecção em seu poder de tal modo que se possa refletir de sangue frio se se deveria ficar zangado ou não, parece algo contraditório. (KANT, 2006, p. 151).

Em outro exemplo:

O rico a quem um criado quebra por inépcia uma bela e rara taça de cristal ao carregá-la durante uma festa, não devia dar nenhuma importância a isso, se no momento mesmo comparasse essa perda de um prazer com a quantidade de todos os prazeres que sua feliz situação lhe confere na condição de homem rico. Mas se se entrega única e exclusivamente a um sentimento de dor (sem fazer rapidamente em pensamento aquele cálculo), não é de surpreender que seu estado de espírito será tal como se houvesse perdido toda a sua felicidade. (KANT, 2006, p. 152).

Em um estado de afecção o sujeito não tem a capacidade de reflexão, não tem a capacidade de visualizar o todo, não é capaz de enxergar a totalidade, o que há é somente o uno, o momento, a condição atual, o acontecimento presente, o indivíduo é tomado por um único e 
exclusivo sentimento o qual impossibilita a reflexão, náo permite a avaliação da situação vivida e a deliberação sobre ação.

De acordo com a concepção do filósofo, as afecções são, em geral, ataques, acontecimentos, casos ou sintomas, podendo ser divididas em estênicas, as afecçóes procedentes da força ou do excesso de força, e astênicas, as afecçóes concludentes da fraqueza, da ausência de força ${ }^{6}$.

As afecçóes geradas por uma força são de característica mais excitante e por isso são, com mais frequência, exaustivas, em contrapartida, as afecçóes procedentes de uma fraqueza, com frequência, afrouxam a força de vida, por essa razão, preparam o repouso.

No que diz respeito às paixóes humanas, Kant aponta que nesse estado o sujeito também náo é capaz de abarcar a totalidade, porém, no caso da paixão, a totalidade não considerada no momento da escolha, da decisão, da ação, é o todo de suas inclinaçôes - o querer sensível que serve de hábito ao sujeito, o que o indivíduo quer ou deseja face às sensações ${ }^{7}$. Nas palavras do filósofo: "A inclinação pela qual a razão é impedida de comparar essa inclinação com a soma de todas as inclinações em vista de uma certa escolha, é a paixão (passio animi)". (KANT, 2009, p. 163).

Veja, tanto a afecção quanto a paixão, entendidas enquanto estados da alma pertencentes à faculdade de desejar face às sensaçóes, são sempre unas, casos particulares, ou seja, o indivíduo nesses estados apenas é capaz de levar em consideração a condição presente, não é capaz de enxergar o todo.

No caso das afecçôes a totalidade não passível de ser abarcada, o que se dá pela impossibilidade da reflexão, é a dos sentimentos (prazer, alegria, dor, agradável, desagradável, vergonha), somente há o momento e o sentimento presente. No caso das paixốes a totalidade não contemplada é a das inclinações, o que ocorre quando a paixão é a determinante da ação, ou seja, a totalidade daquilo que eu quero.

Vale reforçar que tanto a afecção quanto a paixão são consideradas por Kant enquanto uma inclinação. No caso das afecçôes o que está mais latente, o que é determinante, são sentimentos, os sentimentos que são ou podem ser gerados pela sensação - prazer/desprazer, dor/alegria; no caso das paixôes o que está latente, o que é determinante, é o próprio objeto, isto é, o próprio fim ambicionado, o próprio querer tal ou tal coisa.

No primeiro caso (afecção) há a presença de um único sentimento na base da inclinação, do querer sensível, o qual pode mover o indivíduo em sua conduta, escolhas, decisóes e açóes ou reaçôes. No segundo caso (paixão) há apenas uma inclinação, ou seja, a presença marcante de um único e exclusivo objeto do querer sensível o qual também pode mover o ser humano em sua conduta, escolhas, decisóes e açôes até que ele atinja (o que pode não ocorrer) o seu fim sensível ambicionado. Para o caso da afecção, ter um sentimento determinando a escolha e açôes é conclusão do que significa "ter uma inclinação"; para o caso da paixão, ter um objeto, um fim

6 Embora as espécies de afecçôes tenham sido tomadas de Elementa medicina (1780) do médico escocês Jonh Brown (1735-88), verificamos, com a divisão das causas geradoras da afecção em estênicas, da força, e astênicas, da fraqueza, uma proximidade com o pensamento aristotélico ao apontar as causas geradoras dos vícios, isto é, o excesso ou a falta. "[...] está na natureza das coisas o serem destruídas pela falta ou pelo excesso [...] o que se entrega a todos os prazeres e não se abstém de nenhum torna-se intemperante, enquanto o que evita todos os prazeres, como fazem os rústicos, se torna insensível” ARISTÓTELES. Ética a Nicômaco. Nova Cultural, São Paulo, 1987, p. 28. A questão que se coloca é: será o estado de afecção em Kant um estado de vício? Pensamos obter indícios da proximidade (ou náo) entre afecção e vício no que se segue.

7 A açâa, conforme explica Beck, é um produto da escolha ou decisão que envolve uma vontade. Cf. Lewis White Beck. $A$ commentary on Kant's Critique of Practical Reason. University of Chicago Press, Chicago, 1984, p. 130. 
sensível querido, movendo o ser humano em sua escolha e açôes, também significa a conclusão do que seja "ter uma inclinação".

Tendo em vista que no estado de paixão ainda assim a reflexão é possível "[...] a paixão [...] não tem pressa e reflete para alcançar seu fim, por mais violenta que possa ser" (KANT, 2006, p. 150), por não ser comoçóes passageiras e turbulentas, como é o caso da afecçáo, pode se deixar unir à mais tranquila reflexão ou razão, fixando raízes profundas e concentrando toda a força de conduta, de escolha, de ação do indivíduo em um único fim sensível querido, conforme explica Kant: "[...] se a afecção é uma embriaguez, a paixão é uma doença que tem aversão a todo e qualquer medicamento". (KANT, 2006, p. 163).

“[...] a paixão, ainda que violenta, pode coexistir com a razão, pois é deliberativa a fim de atingir a sua finalidade". (BORGES, 2004, p. 34). Nesse sentido, ao apontar que no estado de paixão a conduta, a escolha, a decisão e a própria ação do indivíduo é movida por um único fim sensível desejado ${ }^{8}$, o qual pode agregar-se a mais tranquila reflexão temos, de acordo com Kant, que a paixão sempre pressupõe uma máxima da ação. Tendo em vista que a paixão, um fim prescrito pela inclinação ou um fim sensível, pode unir-se a mais tranquila reflexão, ou seja, a paixão pode coexistir com a razão do sujeito, podemos dizer, então, que há máximas da ação na ação por paixão. $\mathrm{O}$ mesmo não ocorre com a afecção, a comoção passageira não passível de reflexão. Vale lembrar que a máxima da ação é o princípio ou fundamento subjetivo do querer, o que significa as razóes, a intenção ou o porquê do agente, a razão de ação que um agente tem ou se dá para agir. A máxima geral da ação fornece regras de ação, mediante tais regras uma máxima é capaz de determinar o querer (ou a ação) do agente, porém não podemos esquecer que essa regra, derivada de uma máxima em geral ou material, é oferecida pela razáo empírica, o que significa que está sempre ligada a um objeto sensível do desejo, podendo estar condicionada a esse objeto do querer enquanto determinante da vontade, eis o caso da paixão (estado de paixáo) - a máxima da ação sempre estará ligada um objeto, um fim prescrito pela inclinação - um querer sensível, o qual determina (move) a escolha e a ação em função desse objeto.

Pela possibilidade de união do desejo sensível e a razão envolvidos no estado de paixão, embora seja uma razão prática empírica, a paixão sempre implica uma máxima de ação, um plano ou regra de ação do sujeito, um agir segundo um fim ou para um fim que lhe é prescrito por uma inclinação. Noutras palavras, a paixão pressupóe uma máxima e essa máxima determina o agir segundo um fim, algo ambicionado, desejado, querido, o qual é prescrito pela inclinação - a faculdade de desejar sensível - desse modo, a paixão sempre pressupóe uma máxima da ação ligada a um fim sensível querido.

De acordo com a filosofia moral kantiana, do ponto de vista da moralidade, ou seja, se há a preocupação moral, podemos citar ao menos três problemas ao ter (querer) um objeto, um fim sensível querido, movendo ou determinado as decisões e ações do sujeito, a escolha e a ação determinadas em função do objeto sensível desejado: (i) nada obriga o sujeito a agir desse ou daquele modo, assim, nada exige do sujeito querer sempre fazer o que deve ser feito do ponto de vista da moralidade, por inclinação ora pode fazer, ora não, e, se faz por inclinaçáo (enquanto condição de determinação), o faz quando tiver a inclinação e não o faz quando (ou se) não tiver; ii) se o objeto não existir, se a ação não chegar ao seu objeto, a ação não terá valor algum; (iii) se uma ação é boa por "inclinar-se” para tais e tais fins sensíveis, há então o problema do valor

8 Eis a força de uma paixão, ou seja, o próprio fim sensível querido, o objeto que se quer atingir, uma finalidade específica. 
relativo e limitado da ação segundo (determinada) um objeto sensível querido, afinal o valor de qualquer objeto sensível, mesmo de um objeto sensível desejado, é sempre relativo, e não absoluto.

Vale lembrar que o parágrafo inicial da Fundamentação traz consigo a afirmação oculta de que algo ilimitadamente bom significa algo moralmente bom, com valor moral: "Neste mundo, e até fora dele, nada é possível pensar que possa ser considerado como bom sem limitação a não ser uma só coisa: uma boa vontade”. (KANT, 1980, p. 109). Na filosofia moral de Kant moralmente bom significa absolutamente bom, há uma equivalência entre algo ilimitadamente bom com o valor moral (o bom moral), ou seja, para ser moralmente bom, de acordo com a concepção de Kant, deve ser bom sem reservas. O que não parece ser o caso das inclinações, seja ela caracterizada enquanto paixão ou afecção, que além de não ser absolutamente boa, pode revelar intençôes egoístas, pode ora levar ao bem, ora ao mal e pode não exigir do ser humano a ação. Nesse sentido, nenhuma ação será moralmente válida se for conduzida meramente pelo desejo sensível particular, se a condição de determinação da ação for meramente o desejo específico.

$\mathrm{O}$ que devemos ter em mente, se quisermos nos manter fiéis a proposta kantiana de moralidade, é que há a distinção entre a matéria da vontade, isto é, o fim sensível querido, o qual pode ser derivado do estado de paixão - um fim que é posto pela inclinação, diferentemente do fim sensível querido, o objeto do desejo sensível, enquanto fundamento determinante da vontade, das escolhas e das decisóes de açóes.

O ponto de Kant é meramente que as ações de um determinado ser humano somente terão valor moral quando o princípio prático objetivo enquanto motivo/determinante toma o lugar da mera inclinação. E disso, naturalmente, é completamente diferente de reivindicar que o valor moral requer a ausência de toda e qualquer inclinação, afecção, paixão. Eis o primeiro ponto a ser esclarecido no que diz respeito à esfera prático-sensível, em particular, para o caso da paixão, ação e valor moral.

O segundo ponto que devemos compreender é que na esfera prático-sensível ${ }^{9}$, a razão, o motivo ou o porquê da ação não deve satisfazer uma única inclinação, ou seja, a ação não deve ser realizada segundo um princípio que leva em consideração somente uma única inclinação colocando as todas as demais de lado, mas antes, deve (razóes, motivo, porquê) observar se aquela inclinação pode coexistir com a soma de todas as inclinaçôes. O outro problema do estado apaixonado, além e em decorrência de poder se deixar guiar pelo objeto enquanto condição, é justamente não abarcar a totalidade, ou seja, pode haver a paixão - um fim posto pela inclinação, porém não enquanto razão de determinação ao ponto de, por exemplo, ignorar o todo - a totalidade das inclinaçóes.

Tomemos o exemplo posto por Kant:

O desejo de glória de um homem sempre pode ser uma direção de sua inclinação aprovada pela razão, mas o ávido de glória também sempre quer ser amado pelos outros, ele necessita do relacionamento agradável com os demais, da conservaçáo de sua fortuna e coisas semelhantes. Se, porém, é apaixonadamente ávido de glória, ele é cego para esses fins aos quais igualmente é conduzido por suas inclinaçóes, e que seja odiado pelos outros, ou que fujam do contato com ele, ou que corra o

9 Prático: a ação considerada do ponto de vista da moralidade. Sensível: porção sensível do ser humano - paixões, afetos, impulsos, inclinações [...]. 
risco de empobrecer por seus gastos - isso tudo ele não vê. (KANT, 2006, p. 164).

Desse modo, segundo Kant, um desejo sensível pode ser aprovado pela razão (princípio formal - embora com dificuldades), porém o que ocorre no estado apaixonado, o agir por paixão, é que o indivíduo geralmente faz de uma parte dos seus fins, o todo, ou seja, a razão única de suas açôes, o que contradiz diretamente a razão mesma (motivos/porquês) em seu princípio formal, vale dizer, o fundamento incondicionado, universal e necessário. De acordo com Kant (2006, p. 164), o fim sensível querido em sua melhor índole ainda que se dirija àquilo que pertence (segundo a matéria) à virtude, tão logo quando envolve a paixão pode ser (segundo a forma) moralmente reprovável.

Tendo em vista a preocupação moral e as consideraçóes kantianas, Paton observa que devemos, entâo, perguntar se poderíamos agir não meramente por uma inclinaçáo (ou paixão um fim prescrito pela inclinação) sob uma regra a qual nos propomos mediante o objeto sensível querido, mas antes por inclinação ou paixão e ao mesmo tempo sob um princípio válido do ponto de vista formal, ou seja, necessário e objetivo. O que significa dizer agir sob um princípio que possui validade e alcance independentemente desse ou daquele querer sensível, mesmo que haja o querer ${ }^{10}$.

Os desejos sensíveis podem apresentar uma hierarquia e podem controlar as açóes humanas, fazendo o ser humano agir sob sua guia. Mas, tendo em vista que tais desejos sensíveis são geralmente fundados por uma "obrigação" condicionada, para termos um fundamento incondicionado, necessário e universal de nossas açôes, o princípio que Kant buscou, chamada por Beck (1984) de máxima suprema, não pode ser governado em virtude da matéria, objeto sensível querido, embora não haja problema na sua existência, em querê-lo.

Dito de outro modo, a máxima da ação do indivíduo que age com paixão, a máxima da ação resultante de querer um fim posto pela inclinação, pode converter-se em uma máxima moral? Vale lembrar nesse momento que, segundo Kant, o princípio prático objetivo nos coloca a questão de saber se o princípio prático subjetivo do querer (a máxima da ação) pode valer ao mesmo tempo enquanto princípio prático objetivo do querer (lei). Eis aqui a diferença entre agir com paixão e agir por paixão. Um dos problemas apontado pelo filósofo em agir por paixão é, precisamente, fazer de uma parte dos seus fins o todo - o único motivo e condição de suas açôes, o que implica, ademais, no valor condicionado, não absoluto e relativo, da vontade.

No campo da moralidade, ou seja, se há a preocupação moral, de acordo com Kant, a máxima (geral) da ação que é sempre subjetiva, ou seja, válida para um sujeito em particular em função da sua adoção e/ou em função dos seus fins, deve ser capaz de incorporar a lei prática objetiva que é sempre objetiva, válida para todos sem exceção. Desse modo, a máxima da ação (ou lei/máxima moral) será válida para todos e ao mesmo tempo válida, por ser adotada, para si próprio. A escolha individual poderá ser a escolha de todos - independentemente de haver ou não o objeto sensível do querer e mesmo que haja o desejo sensível. A excelência moral, de acordo com Kant, reside em, por exemplo, fazer o bem mesmo na ausência da afecçáo ou paixão em relação ao outro.

Por fim, vale ressaltar que na Antropologia Kant alerta para o fato da fragilidade de uma inclinação, seja ela uma afecção ou uma paixão, o que vale igualmente as para outras emoçóes,

10 Hebert James Paton. The categorical imperative. A study in Kant's moral philosophy. University of Pennsylvania Press, Philadelphia/Pennsylvania, 1971, pp. 136-137. 
sensaçôes e sentimentos, a fragilidade de se agir por inclinar-se a tal ou tal coisa, ocorre, pois, no estado de afecção o indivíduo não é capaz de reflexão, o motivo de sua ação será sempre um único e exclusivo sentimento (ação por afecção); no estado de paixão, embora haja a possibilidade de reflexão, a razão do indivíduo dificilmente pode dominar tal estado, o querer tal e tal coisa, o objeto sensível do desejo, é intenso, é violento, é marcante e acaba por mover (ação por paixão) a vontade do indivíduo. Algumas passagens da Antropologia ilustram essa posição:

[...] A afecção atua sobre a saúde como um ataque apopléctico; a paixão, como uma tísica ou definhamento [...] A afecçâo pode ser vista como a bebedeira que se cura dormindo, mas que depois dá dor de cabeça; a paixáo, porém, como uma dor de cabeça causada por ingestáo de um veneno ou como uma atrofia, que necessita interna ou externamente de um alienista que saiba prescrever quase sempre paliativos, mas contra o qual no mais das vezes não remédios radicais [...] A afecção pode ser vista como uma bebedeira que se cura dormindo;a paixáo, como uma loucura que cisma com uma representaçáo que deita raízes cada vez mais fundas [...]. (KANT, 2006, p. 150-152).

Segundo a concepção de Kant, a afecção enquanto um sentimento, uma comoção tempestuosa e passageira, impossibilita a reflexão e, desse modo, a própria deliberação sobre açáo. A paixão, por outro lado, ainda que violenta, pode coexistir com a razão prática, é deliberativa, porém há sempre uma finalidade a se atingir, desse modo, tendo em vista a existência marcante do objeto sensível do querer, a razáo do indivíduo dificilmente pode dominar o estado de paixão (ou querer a coexistência entre a razão e a paixão) pois, mesmo que a paixão possa se referir às atitudes deliberativas, possa coexistir com a razão prática, pode, também, exigir, por exemplo, a mais ardilosa dissimulaçáo, caso isso seja preciso ou possa contribuir para obter o determinado objeto sensível do desejo - o seu querer sensível.

Kant aponta que um indivíduo quando age por uma afecção e a sua ação é distinta da ação com valor moral, distinto daquilo que o dever prático ordenaria, pode ser caracterizada apenas enquanto uma fraqueza da vontade, isso tendo em vista que a afecção é caracterizada por Kant enquanto comoções passageiras, enquanto que a ação por paixão quando é distinta da ordem da razão prática, da ordem do dever-ser, daquilo que deve necessariamente acontecer no âmbito da moralidade, por pressupor uma máxima, pode ser mais prejudicial do ponto de vista moral, afinal a máxima da paixão pode não poder ou querer coexistir com a máxima moral. O objeto de uma paixão quando contrário à lei, contrário à adoção da lei numa máxima que determina ou pode determinar a vontade, é, segundo Kant, malévola e resulta em vício.

Noutras palavras, quando houver a incompatibilidade do objeto do desejo com a máxima formal, o sujeito, por querer apaixonadamente o objeto, pode recusar querer a máxima moral, o princípio prático objetivo, negar ou não seguir o seu dever prático, resultando em uma ação viciosa. Nesse sentido, podemos dizer as consequências morais negativas das afecçôes são menores do que a persistência das máximas de uma paixão ${ }^{11}$.

Quando há a compatibilidade entre a ação por afecção e a prescrição do dever-ser, trata-se de um acaso, visto que no estado de afecção a reflexão e deliberação não são possíveis e, segundo

11 Devemos reforçar que a ação por afecção ou a ação por paixão não irão apresentar em nenhuma hipótese o valor moral, afinal quando investigado as causas da ação, o que determinou/moveu a vontade, encontrará algo diverso do dever prático, a única ação, segundo Kant, com genuíno valor. O que não implica na recusa ou ter que abolir com toda e qualquer afecção e/ou paixão. Pode haver a paixão, ela pode, embora difícil, coexistir com a razão prática, mas, se há a preocupação moral, a paixão (ou a afecção) não pode apresentar-se enquanto a razão de determinação da ação, o que move ou determina a vontade, em suma, o motivo (Bewegungsgrund) - princípio objetivo do querer. 
Kant, não é seguro deixar ao acaso o valor moral das ações humanas, eis, ademais, a necessidade do princípio supremo da moral fundado na Fundamentação da metafísica dos costumes e na Crítica da razão prática. Para o caso da ação por paixão, a coexistência entre razão prática e a paixão é possível, no estado de paixão a reflexão e deliberação são possíveis, mas, conforme vimos, pode ser algo difícil, o que se dá exatamente pela força do objeto sensível do desejo indissociável do estado de paixão.

No que diz respeito à coexistência entre o estado de paixão e a razão prática, há duas alternativas: i) a máxima da paixão incompatível com a máxima moral e, nesse sentido, a paixão pode resultar em vício; ii) a máxima resultante de uma paixão compatível com a ordem da máxima moral e, nesse sentido, referir-se a uma ação virtuosa. Porém, mesmo quando houver a compatibilidade ou a coexistência entre a razão prática e a paixão, a razão (o porquê ou o motivo) da ação, se há a preocupação moral, será sempre o dever: o respeito, o reconhecimento e a adoção da lei prática, o respeito, o reconhecimento e a adoção em sua máxima da ordem do dever-ser, em suma, o princípio prático objetivo. Independentemente de qualquer subjetividade e móbeis: sentimentos, interesses, impulsos, inclinaçôes, paixões, emoçôes, afecçôes (mesmo que haja) ${ }^{12}$.

Ainda de acordo com Kant, as afecçóes e as paixôes de um sujeito podem impulsionar uma açáo boa do ponto de vista da moralidade, na qual, por exemplo, o respeito (reconhecimento e adoção) pela lei prática, o princípio prático objetivo, não é um móbil, o princípio subjetivo do querer, suficiente. No entanto, nestes casos, a moral é provisória, afinal, embora afetado por esse ou aquele sentimento, ou apaixonado, o interesse direto nesse ou naquele objeto sensível, muito embora a ação tenha sido realizada conforme o dever (o que deve acontecer do ponto de vista moral), o que afeta, interessa ou impulsiona o sujeito hoje pode náo necessariamente afetá-lo, interessá-lo ou impulsioná-lo amanhã e, caso não afete ou interesse, pode-se deixar de fazer o que dever ser feito, vale dizer, o que deve ser feito na esfera da moralidade - a ação com valor moral.

Conforme explica Borges (2004, p. 33), o que existe nos casos das boas açóes impulsionadas por uma afecçáo ou uma paixão, é uma moral provisória que, empiricamente, pode utilizar os sentimentos (afecçóes) e interesses (paixão), por exemplo, pela sorte alheia, para fomentar as boas açôes (açôes que são compatíveis com as ações com valor moral, embora sem o genuíno valo moral), até a razão do indivíduo tenha amadurecido o suficiente para não mais precisar dos sentimentos ou interesses enquanto a razão de determinação da ação, visto que ora pode haver o sentimento ou o interesse, ora não. $\mathrm{O}$ mesmo não ocorre, segundo o pensamento kantiano, na ação por dever, com a noção do dever moral quando este é despertado, vale dizer que: "Quando há a (cons) ciência do dever e o homem não segue (não o realiza) é como se isso lhe causasse uma espécie de asco, de repulsa”. (KANT, 2008, p. 07).

12 Borges, aponta que a obra de Kant apresenta várias referências acerca da dificuldade de determinarmos o valor moral das açôes, visto que não é possível o acesso aos motivos e aos móbeis alheios, a mera observação da ação não nos garante a sua moralidade, o seu valor moral, ou seja, náo nos oferece acesso à moralidade destas. Por exemplo: "[...] o merceeiro pode não aumentar seu preço por dever ou por interesse egoísta [...]" Como ter acesso aos seus motivos e móbeis? Maria de Lourdes Borges. Amor. Zahar, Rio de Janeiro, 2004, p. 02. Pensamos que, embora não verificáveis externamente e tendo em vista a dificuldade de acesso ou avaliação dos motivos e móbeis da ação, a açáo com valor moral pode ser presente, eficaz e efetiva na vida humana mediante a formação/desenvolvimento moral, formação e desenvolvimento do caráter via educaçáo, vale dizer, a educação conforme concebida pelo filósofo. Formando para a moralidade, mesmo a moralidade em Kant sendo algo interno/íntimo - "[...] quando se fala de valor moral, não é das açôes visíveis que se trata, mas dos seus princípios íntimos que não se vêem" Immanuel Kant. Fundamentação da Metafísica dos Costumes. Abril Cultural, São Paulo, 1980, p. 119. Ou seja, o valor moral das ações em Kant diz respeito precisamente às razóes ou o porquê da ação, às razões ou o porquê um agente tem ou se dá ara agir. $\mathrm{O}$ agente (o sujeito da ação/atuante), uma vez desenvolvido à moralidade, será capaz dessa avaliação, será capaz de investigar, saber ou conhecer os seus móbeis e motivos. 
As açóes impulsionadas ou por afecçôes e/ou paixôes podem estar em acordo ou não com a boa ação, com o bom moral e, mesmo em acordo, quando investigado as causas, os motivos da ação, ele certamente carecerá de valor. Além disso, o que o sujeito faz hoje em nome de uma (por) afecção ou paixão, pode não fazer amanhã, ou seja, hoje pode haver a afecção ou a paixão movendo a sua vontade, amanhã não e senão houver, poderá deixar de agir e fazer o que se deve ser feito também do ponto de vista da moralidade. Nesse sentido, a afecção bem como a paixão, segundo Kant, não são boas guias morais, ademais, tendo em vista a sua vulnerabilidade.

Do ponto de vista da moralidade, embora Kant não negue ou exija a recusa e exclusão de toda e qualquer afecção, paixão, a recusa e exclusão das inclinaçôes em geral, a porção sensível do ser humano, temos que enquanto base da conduta moral, a condição de determinação, motivo, o porquê da ação, não podemos tê-las. A vontade humana pode ser afetada (pode haver), mas não determinada por uma inclinação - seja ela caracterizada enquanto uma afecção (sentimento) ou paixão (interesse direto em um objeto).

A afecção, paixão, inclinação, são todas afirmadas, mas sob a condição de que sua busca seja regulada pelo princípio moral, pelas leis práticas que ordenam açóes enquanto deveres, vale dizer, caso haja a preocupação moral.

A inclinação enquanto determinante se encerra, em última instância, em heteronomia da vontade, a determinaçáo por algo alheio a vontade, diverso da vontade em si. Como se sabe a moral kantiana é uma moral autônoma, para o filósofo, a vontade do ser humano possui a capacidade de fornecer a si a sua própria lei, independente de toda tendência, sentimento ou desejo sensível enquanto condição de determinação, sendo livre por respeitar, adotar em suas açóes e seguir tal lei - respeitar, adotar e seguir a ordem da razão prática.

É válido apontar que, no que diz respeito às inclinaçóes e a razão prática, Kant aponta que estamos diante de duas espécies de bem - o bem físico (sensível) e o bem moral (moral ou intelectual), os quais não devem ser confundidos, embora seja difícil não os confundir pois, caso confundidos ou misturados se anulam e não contribuem para o verdadeiro fim da ação ${ }^{13}$. A primeira espécie de bem, o bem físico, é o bem-estar, o da segunda espécie, o bem moral, é a virtude; tendo em vista o valor da ação, alerta Kant, a inclinação (sentimento, desejo, impulso [...]) para o primeiro deve ser limitada pela lei do segundo ${ }^{14}$.

Por exemplo: a sociabilidade (Umgänglichkeit), segundo Kant, é uma virtude, no entanto, a inclinação ao relacionamento frequentemente se converte em paixão. Nas palavras do filósofo: "[...] se a fruição das relaçôes sociais se torna presunçosa pela obstinação, essa falsa sociabilidade cessa de ser virtude e é bem-estar que prejudica a humanidade”. (KANT, 2006, p. 174).

Veja, Kant não nega o bem-estar (o bem físico), ao contrário: O purismo do cínico [...] sem bem-estar social, são formas desfiguradas de virtude e não convidam para esta [...] abandonados pelas Graças, não podem aspirar à humanidade. (KANT, 2006, p. 178).

Porém, quando o bem-estar toma o lugar da virtude, ou seja, o bem-físico toma o lugar/ papel do bem moral enquanto razão de determinação das escolhas, das açóes, da conduta, tendo em vista o valor moral da ação que é de longe o mais alto, torna-se algo que pode prejudicar o ser humano e a sua a própria Humanidade.

13 Se há a preocupação moral, o fim da ação será moral - o próprio valor moral da ação.

14 Enxergamos esse limite enquanto o respeito, reconhecimento e adoção do princípio prático objetivo. 
Para o caso da sociabilidade Kant nos oferece alguns exemplos pragmáticos, que auxiliam na compreensão da sociabilidade enquanto uma virtude, bem como o bem físico (bem-estar) assumindo o lugar do bem moral (moralidade) enquanto condição das açôes, vejamos.

A música, a dança, o jogo, tornam uma reunião social silenciosa, em particular na situação do jogo, as palavras necessárias náo são capazes de estabelecer uma conversaçáo que requer comunicação recíproca de pensamentos, isto é, a sociabilidade. $\mathrm{O}$ jogo, de modo geral, somente é capaz de preencher o vazio da conversação após, por exemplo, uma refeição, desse modo, não remete à sociabilidade. De acordo com Kant:

O jogo [...] é em geral a coisa que mais importa, como meio de aquisição em que afecções são intensamente agitadas, em que se estabelece uma certa convenção de interesses pessoais para se saquearem uns aos outros com a maior cortesia, e, enquanto dura o jogo, um completo egoísmo é erigido em princípio que ninguém renega $^{15}$. (KANT, 2006, p. 175).

Eis, ademais, a tentativa de unir, confundir ou misturar o bem-estar social com a virtude da sociabilidade, o que implica na impossibilidade de se esperar o verdadeiro fim moral da ação. De modo decisivo, de acordo com Kant, o bem-estar social, as relações sociais, a reunião social, as quais podem gerar certo bem-estar fisco, náo remete necessariamente à sociabilidade. A sociabilidade (pequena sociedade) ${ }^{16}$ tem de se propor não tanto a satisfação do corpo (afecçôes, interesses, o querer sensível) o que cada indivíduo pode obter isoladamente, mas antes o contentamento social, para o qual aquela (bem-estar social) tem de parecer ser apenas o veículo, não o motivo.

Em outro exemplo, diz Kant: "O homem que, ao se alimentar, consome a si mesmo pensando durante a refeição solitária, perde pouco a pouco a alegria que adquire quando um companheiro de mesa the oferece" (KANT, 2006, p. 177). Eis outro dado nocivo à sociabilidade, vale dizer, a virtude da sociabilidade. A posição de Kant é que por mais insignificantes que possam parecer as refinadas leis sociais se comparada com as leis práticas (ainda que somente consista em meras máximas) trata-se um "traje que veste vantajosamente a virtude" - a ação virtuosa, com valor moral e que pode ser recomendado. Como explica Louden: "A antropologia moral, é assim, também um tipo de conhecimento útil ou prático, mas os usos a partir dos quais ela deve ser realizada são morais e não meramente pragmáticos”. (LOUDEN, 2002, p. 38).

\section{Consideraçóes finais}

Após a análise e a exposição da afecção e da paixão no âmbito da antropologia filosófica de Kant, entendidas enquanto elementos da constituiçấo sensível do ser humano, enxergamos que, embora do ponto de vista da moralidade kantiana, não haja a necessidade de aniquilar, excluir ou negar as afecçôes, as paixóes, bem como qualquer inclinação, elas não se apresentam (não podem se apresentar) enquanto um bom ou seguro fundamento moral.

A exclusão da paixão ou da afecção, tendo em vista a própria constituição dual do ser humano, um ser racional $e$ sensível, não seria possível, pois a razão precisa da experiência para reconhecer-se nela, dito de outro modo, as ideias da razão necessitam de alguma relação com a

15 Immanuel Kant. Antropologia de um ponto de vista pragmático. Iluminuras, São Paulo, 2009, p. 175. Grifos acrescentados.

16 Lord Chesterfield (1694-1773) dizia que ela não deve ser inferior ao número das Graças nem superior ao número das Musas. Eis também o princípio de Kant. 
experiência na medida em que, sendo o ser humano um ser também sensível além de racional, ele não pode abandonar a sua porção sensível em detrimento da sua racionalidade. A experiência, segundo Kant, pode ser uma boa escola (conhecimento teórico) para o ser humano, mas ela (a experiência) não basta, não é suficiente por si só, para aperfeiçoar os seus conhecimentos e tornálos conhecimentos práticos e efetivo.

Seguindo com as consideraçóes kantianas na Antropologia, podemos afirmar, em definitivo, que a paixão, a afecção, de modo geral toda inclinação, ou seja, aquilo que me inclina a tal ou tal coisa por esse ou aquele móbil ou sentimento, não são bons fundamentos morais, a condição de determinação da ação que possa ter o seu valor, isto é, não são capazes de conferir o valor da ação - valor moral ou do caráter - o valor moral do caráter é, para Kant, o essencial do ponto de vista da moralidade.

\section{Referências}

ALLISON, Henry. E. Kant's theory of freedom. NewYork: Cambridge University Press, 1990.

BECK, Lewis White. A commentary on Kant's Critique of Practical Reason. Chicago: University of Chicago Press, 1984.

BORGES, Maria de Lourdes. Amor. Rio de Janeiro: Zahar, 2004.

KANT, Immanuel. Fundamentaçáo da Metafísica dos Costumes. São Paulo: Abril Cultural, 1980.

KANT, Immanuel. Crítica da Razão Prática. São Paulo: Martins Fontes, 2003.

KANT, Immanuel. Antropologia de um ponto de vista pragmático. São Paulo: Iluminuras, 2006.

KANT, Immanuel. Akademieausgabe von Immanuel Kants Gesammelten Werken.

Disponível em: <http://www.korpora.org/kant/verzeichnisse-gesamt.html>. Acesso em $15 \mathrm{de}$ agosto de 2013.

KANT, Immanuel. The Metaphysical elements of ethics. Hong Kong: Forgotten Books, 2008.

LOUDEN, Robert B. A segunda parte da moral: a antropologia moral de Kant e sua relação com a metafísica dos costumes. IN: Ethic@. Florianópolis, v. 1, n. 1, jun. 2002, p. 27-46.

PATON, Hebert James. The categorical imperative. A study in Kant's moral philosophy. Philadelphia/Pennsylvania: University of Pennsylvania Press, 1971. 